\title{
Colonial Legacy of Language Politics and Medium of Instruction Policy in India
}

\author{
Authors: \\ Shivakumar Jolad* and Isha Doshi** \\ *Associate Professor (Public Policy), FLAME University, Pune- 412115, Maharashtra, INDIA \\ Email: shivakumar.jolad@flame.edu.in \\ **formerly at FLAME University, Pune, 412115, Maharashtra, INDIA \\ Email: isha.doshi@flame.edu.in
}

\section{Abstract}

The sphere of language politics within India has been a complex one, and rightly so, owing to the country's rich and immense linguistic diversity. Naturally, this complexity has trickled into the Medium of Instruction (MOI) used in Indian schools. Hindi, English, and state languages dominate the school MOI undermining the enormous Language and Mother Tongue diversity in India. Even though the Indian Constitution and the three National Education Policies have emphasized Mother Tongue/Local language as the MOI at the primary education level, there continues to be a divergence between policy and the actual MOI used in government and private schools in India. In this article, we argue that the political hegemony of languages and its reflection in the MOI at present derives from the historic domination of classical languages in the pre-colonial era and its replacement by English in the colonial era. We trace the MOI in indigenous schools of the 19th Century and assert that their elasticity and adaptability was suited to local conditions. We argue that formal western education created rigidity and homogeneity through centralized curriculum and common language. We discuss the ambivalence of East India Company and British India's policies on medium of Instruction in English and Vernacular languages. We highlight different phases of anglicization of Education in India, and its adoption and expansion by Indians. We argue that despite attempts at reinvention of education by national leaders and push for Mother Tongue as MOI in the early 20th century, English continued to dominate Indian education.

Keywords: Language Policy, Medium of Instruction, Colonial India, Mother Tongue, English Education, Language Diversity, Minority Languages

\section{Introduction}

Since the introduction of the formal western education system, it took close to two centuries to ensure the three main goals of Universal Elementary Education. In elementary education, India has achieved Universal Access, near Universal Enrollment, and largely ensured Universal retention. Yet, India is lagging behind in the primary goal of education- learning. It is widely 
acknowledged that India is facing a foundational learning level crisis. According to NEP-2020, Once children fall behind on foundational literacy and numeracy, their learning curves will be flat for years and are perpetually unable to catch up.

There is widespread consensus among educationalists, linguistics, early childhood education experts, and cognitive psychologists that instruction in the Mother Tongue of the child is the most suitable medium for cognition and comprehension in the early years (Ball, 2010; see Khaitan, 2020; Daniyal, 2020). According to the Global Education Monitoring Report 2016, children taught in a language other than their own can negatively impact their learning. The imposition of a single dominant language as the language of instruction in schools leads to wider issues of social and cultural inequality (UNESCO, 2016). Mother-tongue-based bilingual education significantly enhances the learning outcomes of students from minority language communities (Ball, 2010; Bühmann \& Trudel, 2008).

There is formal recognition of the importance of Mother Tongue (MT) instruction in the Indian Constitution and the National and state education policies formulated thereafter. Article 350A of the Constitution states that the "state shall endeavour to provide adequate facilities for instruction in the mother tongue at the primary stage of education to children belonging to minority groups" (Constitution of India, 2008). The Three-Language Formula (TLF) in 1957 proposed the use of a mother tongue/regional language, Hindi, and/or English at different levels of education. The TLF was endorsed in the National education policy of 1968 and 1986 has emphasized that the Medium of Instruction (MOI) at the elementary level should be in the Mother Tongue of the child, and directed the states to ensure in state-run schools (Mohanty, 2008). The recent National Education Policy (NEP)-2020 of India broadens the definition of Medium of Instruction (MOI) to include local and regional language at least till grade 5, preferably till grade $8^{\text {th }}$ (Ministry of Human Resource Development, 2020).

Among the languages spoken and used in official and commercial contexts, there is a hierarchy of dominance, with English and Hindi occupying the top, followed by major languages of the states. At the bottom are the marginalized indigenous and minority languages often listed as the non-scheduled languages in the Census (Mohanty, 2008; Benedikter, 2013). The diversity and the power hierarchy of languages shaped through historical and political forces have posed challenges to Mother Tongue as the Medium of Instruction in India since pre-colonial times. State patronage in favour of the dominating languages is evident in the MOI currently used in Indian schools. Ever since independence, state patronage has largely been restricted to the scheduled languages listed in the Constitution. The state has used arguments such as national unity and economic development to enact various language policies at the union and state levels that have privileged a few major languages with official recognition, while depriving minority language speakers of their linguistic rights. In the manner that the existing language policies have birthed a hierarchy of languages, minority speakers are forced to renounce their mother tongues for their children to be able to receive standard education through the medium of a dominant language. 
The hierarchy and dominance of languages reflected in Medium of Instruction used in Indian languages can be traced to five factors: (i) historical state patronage to classical languages in feudal India at the cost of neglect of vernaculars, (ii) introduction of Western Education with English as the main language and medium of instruction in the colonial era, (iii) widespread adoption of English education by Indians in colonial India, (iv) selective patronage of Hindi and official languages of the state after the linguistic reorganization of states, and (v) explosive growth of private schools with English as MOI post-liberalization era. In this article, we trace the first three factors, focusing on the evolution of the Medium of Instruction debate from the colonial era in India and the domination of language as state power.

\section{Language and Medium of Instruction in Indian Schools}

India is one of the most linguistically diverse countries in the world, ranking $4^{\text {th }}$ in terms of the number of languages spoken (Ethnologue, 2019 August 20). The diversity of language and dialects has also been a major barrier to educating the children in their mother tongue ever since the formal Western education system has been introduced in the early 19 th Century. India is replete with multilingualism, with hundreds of distinct official languages, and several hundred recognized and unrecognized dialects. These belong to four major language families: Indo-European, Dravidian, Tibeto-Burmese, and Austro-Asiatic family. (Grierson 1927, Census India C-16, 2011). Estimates of language and dialects vary by the type of survey or the Census used. Census 2011 lists 121 languages and 270 Mother tongues, which excludes languages spoken by less than 10,000 people of the country . The Ethnologue documents 447 languages in India (Eberhard et. al, 2019), while the People's Linguistic Survey estimates an even higher number of 780 living languages (Devy, 2014).

The four dominant patterns in the MOI used in schools are: (1) Pan-Indian languages - English and Hindi, (2) Dominant regional languages, (3) Neighbouring regional languages, and (4) Tribal and other minority languages as preparatory media (Khubchandani, 2008). The number of languages used in schools as either medium of instruction or as a subject has declined from 81 in 1970 to 41 in 1998 (Mohanty, 2006, Mohanty et. al, 2010). Although reliable recent statistics are not available, an analysis of the data by the Universal District Information System of Education (UDISE) 2017-18 reveals that only 23 languages are used as the main medium of instruction (MOI-1), with Pan-Indian languages- Hindi and English medium being among the top two, followed by regional languages such as Bengali and Marathi used by the Indian states (UDISE- Ministry of Education, Government of India, 2017-2018). The majority of the Nonscheduled languages are either not used as MOI, or relegated to the auxiliary medium of Instruction (Benedikter, 2013; Khubchandani 2008).

Nationally, about $44 \%$ of the schools use Hindi as an MOI. Due to Census classification issues, many languages are clubbed as Mother Tongues under a dominant language. Census 2011 lists 56 Mother tongues under Hindi (spoken by more than 10,000 people), wherein some like Bhojpuri, Rajasthani, Chhattisgarhi and Magadhi have more than 10 million speakers each. Yet, in the states where these languages are spoken, Hindi dominates in all the state-run schools as MOI. 
At the same time, English is used widely in higher education institutions and government documents and has attained the de facto status as lingua franca in all commerce and industry in India. The demand for English education continues to dominate, in spite of various attempts such as the Three Language Formula (TLF) to promote and incorporate vernacular languages in Indian education. As a result, there has been a drastic increase in the number of English medium schools both in urban and rural areas. However, the poor quality of English teaching in rural areas continues to further the divide between the rich and poor. Census 2011 data reveals that only $0.02 \%$ of Indians identify English as their mother tongue/home language (Jolad and Agarwal, 2020). UDISE 2017-18 statistics show that out of 17 thousand out of 154 thousand schools (11.2\%) use English as the main medium of instruction (UDISE- Ministry of Education, Government of India, 2017-2018). Some states like Nagaland, Arunachal Pradesh, Sikkim, and Jammu and Kashmir have adopted English as the main MOI in nearly all schools, with other dominant languages (Hindi, Urdu, and the lingua franca of regions) as auxiliary languages or preparatory media.

Much of the domination of Hindi in the education system stemmed from the same attitudes that initially ascribed languages like Sanskrit with greater status during the medieval era, while the domination of English stemmed from its use as the official language and medium of instruction in schools during the colonial era. English education was soon seen as an instrument of upward mobility in India and has continued to be viewed as superior even after gaining Independence. Consequently, India has witnessed the creation of an English-speaking elite as a byproduct of the infiltration of English in the education system since the colonial era, who now dominate and drive the narrative of Indian development and policy. Thus to be able to fully understand the political climate of the present, a careful historical analysis of linguistic imposition becomes particularly important.

\section{Power and Domination of Languages in India}

\section{Medieval Era}

\section{A. Sanskrit and Persian}

The phenomenon of linguistic hegemony for the Indian polity can be traced back to the classical periods of the Gupta and Mughal empires. The classical language Sanskrit was never the lingua franca of the masses in any recorded phase of Indian history, but it received state patronage from Hindu kings from Vedic times to the Colonial era (Anand, 1999). The linguistic domination of Sanskrit during the Gupta period was particularly monumental in perpetuating Brahminical hegemony, as it emerged to be a language of the intellectual ruling elite, with texts such as the Manusmriti and Gita barring women and members of the Dalit and Bahujan class from speaking or even hearing the language (Anand, 1999). Similarly, the Mughal Empire saw the rise of Persian as the language to be utilized across all levels of administration, rendering 
it be viewed as a language "of the king, the royal household and the high Mughal elite" (Alam, 1998, p. 324). As these languages took precedence, they became increasingly associated with power and domination, and the affairs conducted in Sanskrit and Persian became further removed from the experience of the common man. Sanskrit, Arabic, and Persian remained the dominant medium of higher education and was patronized by the rulers in medieval India. The East India Company continued state patronage to Oriental learning in the late 18th and early 19th Century.

While the use of classical languages of Persian and Arabic eventually died out, our analysis of the school data from UDISE 2017-18 shows that Sanskrit continues to be used as a language (under TLF) in about 14,148 schools, with 610 schools claim to be using it as the main medium of Instruction. This is despite the number of mother tongue Sanskrit speakers being only a little over 24,000 (Census 2011 C-16, 2011) i.e. comprising merely 0.00198 per cent of the Indian population. Nevertheless, Sanskrit continues to be accorded the status of a Scheduled Language and not a minority language under the Indian Constitution.

\section{Medium of Instruction in indigenous schools at the beginning of the 19th Century}

In medieval India, the indigenous system of education in villages and towns was conducted through a system of Patashalas (schools) and gurukul (residential schools/college) for Hindus, and maktabs (schools) and Madrassa (higher education) for Muslims. They functioned primarily through the support of the local community without much state patronage (Khubchandani, 2008). During the early consolidation of power by the East India Company in the early 19th Century, surveys were conducted to map the form, content, and spread of indigenous education in India. The reports of Madras Presidency (1822-26), Bombay (182329), and a few districts of Bengal (1835-38) noted the widespread prevalence of informal indigenous schools throughout India (Naik \& Nurullah, 1974, pp. 3-4 ).

The Madras Presidency (1822-1825) extended from Cape of Cameron to Vizagapattanam spanning current Tamil Nadu and Andhra Pradesh (as shown in the map above), parts of Karnataka and Kerala. It had speakers of all dominant south Indian languages and Oriya. Sir Thomas Munro, Governor of Madras, in his minute 25th June 1822, noted that the Madras Presidency had 12,498 schools with 188,650 scholars (184,110 males and 4,540 female) for a 12.8 million population, amounting to one school (informal) to every 1,000 of the population (Arbuthnot, 1855). Homeschooling was noted to be much more prevalent than regular schools. An analysis of the Munro report in 1823, presented in Table 1, shows that one presidency had a mix of all dominant south Indian languages and Oriya. District collectors, such as those from Bellary, also noted that many languages were used even in one single district. 


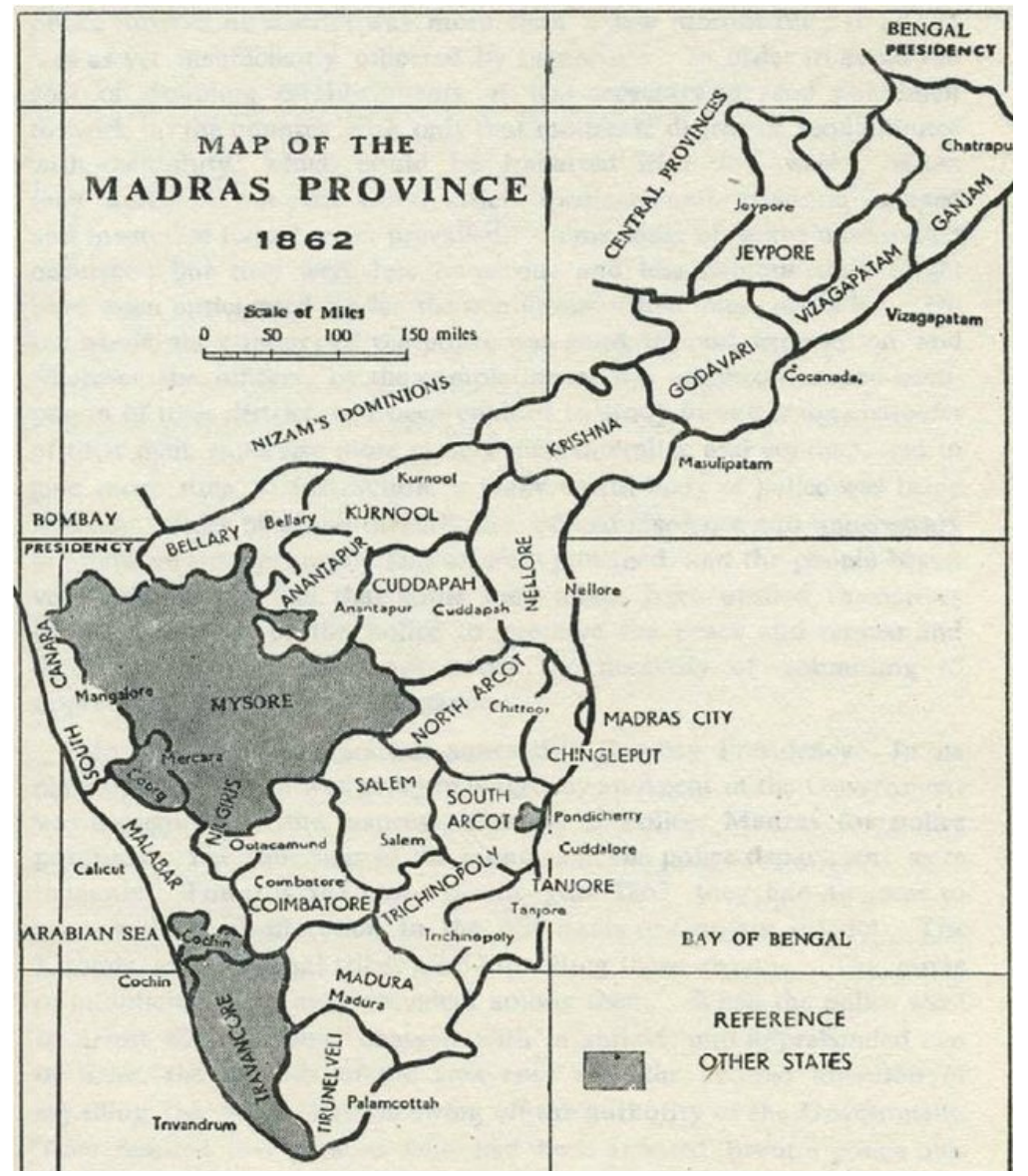

Figure 1: Map of Madras Province in 1859

Image source: The history of Madras police: Centenary 1859-1959 Inspector General of Police- Madras, 1959 (Publication before 1978. Not covered under US copyright law)

Table 1: Languages used in Indigenous schools in Madras Presidency in 1820s

\begin{tabular}{|l|l|l|l|}
\hline Language & No. of Schools & Students in Schools & Total Population (1823 estimates) \\
\hline Oriya & 255 & 2977 & $3,32,015$ \\
\hline Telugu & 3,454 & 38,801 & $10,94,460$ \\
\hline Kannada & 551 & 7,268 & $9,59,469$ \\
\hline Malayalam & 759 & 14,153 & $9,07,575$ \\
\hline Tamil & 6,556 & 93,996 & $66,22,474$ \\
\hline Total & $\mathbf{1 1 , 5 7 5}$ & $\mathbf{1 , 5 7 , 1 9 5}$ & $\mathbf{9 9 , 0 9 , 9 9 3}$ \\
\hline
\end{tabular}

(Source: Munro's Report, quoted in Dharampal, 1983) 
Reports from the district collectors, compiled by Dharmapal (1983) also documents that English schools were relatively rare in the mid-1820s in the Carnatic region. The district of North Arcot had 7 English, 40 Persian, 201 Telugu, and 365 Tamil schools. The District of Bellary had an equal number of schools teaching Telugu and Kannada, and 23 Marathi schools.

An enquiry of the Bombay Presidency found the presence of Canarese [Kannada] speakers, particularly among scholars who taught in indigenous schools. These schools were mainly found to be run in temples, dwellings or homes of the teachers themselves, and was open to everyone who could afford it except for those from the lowest castes. There also seems to have been a significant presence of vernacular languages in the form of "commentaries or translations of the Poorans (Puranas), Tales, Dramas, and Scientific works...originally written in the Mharatta [Marathi] language" (T.B Jervis, 1824 as cited in Parulekar, 1945, p. 7). Jervis further notes that such prevalence of vernacular literature among the natives appears "well worth the attention of the Government when printing books for the use of schools and...should be thought advisable to introduce them in the Schools".

William Ward, the Scottish Missionary of Serampore, noted: "almost all villages possessed schools for teaching reading, writing, and elementary arithmetic." (Ward, 1824, pp. 160). William Adams, Baptist Missionary and abolitionist, conducted a survey of Indigenous schools in Bengal and gave a detailed account of schools and the languages of instruction (Ghosh, 2013, pp. 42). In the district of Rajshahi (Bengal), he estimated the number of instructed adults in Nattore and estimated the male literacy to be $6.1 \%$, with female instruction being almost nonexistent. Adams's third report (1838) gives the statistics of the schools and scholars by language in five districts of current West Bengal and Bihar: Murshidabad, Birbhum, Burdwan, South Bihar and Tirhut. Tables 2 and 3 show the dominant presence instruction in Bengali (1099), Sanskrit (353), Hindi (376), and Persian (694) in these districts. Apart from these he also finds a few Arabic (31), English and Girls schools (6). Around 25,000 were instructed in Bengali and Hindi, 2,500 in Sanskrit and 3,600 in Persian and Arabic (Adam \& Basu, 1941).

TABLE 2 -Number of $\underline{\text { Schools }}$ in five districts of current West Bengal and Bihar according to Adams's third report 1838

\begin{tabular}{|l|l|l|l|l|l|l|l|l|l|}
\hline \multirow{2}{*}{ District } & \multicolumn{7}{|c|}{ Number of Schools } & Total \\
\cline { 2 - 10 } & Bengali & Hindi & Sanskrit & Persian & $\begin{array}{l}\text { Formal } \\
\text { Arabic }\end{array}$ & Arabic & English & Girls & \\
\hline Murshidabad & 62 & 5 & 24 & 17 & - & 2 & 2 & 1 & 113 \\
\hline Birbhum & 407 & 5 & 56 & 71 & - & 2 & 2 & 1 & 544 \\
\hline Burdwan & $\begin{array}{l}629+1 \\
\text { (infant) }\end{array}$ & - & 190 & 93 & 3 & 8 & 3 & 4 & 931 \\
\hline South Bihar & - & 286 & 27 & 279 & - & 12 & 1 & - & 605 \\
\hline Tirhut & - & 80 & 56 & 234 & - & 4 & - & - & 374 \\
\hline
\end{tabular}




\begin{tabular}{|l|l|l|l|l|l|l|l|l|l|}
\hline Total & 1099 & 376 & 353 & 694 & 3 & 28 & 8 & 6 & 2567 \\
\hline
\end{tabular}

Source: Adam \& Basu, 1941

TABLE 3 - Number of Scholars in five districts of current West Bengal and Bihar according to Adams's third report 1838

\begin{tabular}{|l|l|l|l|l|l|l|}
\hline \multirow{2}{*}{ District } & \multicolumn{5}{|c|}{ Number of Scholars } & \multirow{2}{*}{ Total } \\
\cline { 2 - 6 } & $\begin{array}{l}\text { Bengali \& } \\
\text { Hindi }\end{array}$ & Sanskrit & $\begin{array}{l}\text { Persian \& } \\
\text { Arabic }\end{array}$ & English & Girls & \\
\hline Murshidabad & 1,080 & 153 & 109 & 26 & 28 & 1,396 \\
\hline Birbhum & 6,383 & 393 & 490 & 73 & 11 & 7,350 \\
\hline Burdwan & 13,190 & 1,358 & 971 & 120 & 175 & 15,814 \\
\hline South Bihar & 3,090 & 437 & 1,486 & 23 & - & 5,036 \\
\hline Tirhut & 507 & 214 & 598 & - & - & 1,319 \\
\hline Total & 24,250 & 2,555 & 3,654 & 242 & 214 & 30,915 \\
\hline
\end{tabular}

Source: Adam \& Basu, 1941

The high number of speakers, scholars and students being taught in vernacular languages across all Presidencies, thus indicates that the indigenous schools adapted to the local language and culture of the communities. Being free of any kind of central authority, indigenous education meted out higher levels of education compared to educational institutions in the West. Mountstuart Elphinstone, Governor of Bombay Presidency (1819-1827) noted, "There are probably as great a proportion of persons in India who can read, write and keep simple accounts as are to be found in European Countries". Although indigenous education was not accessible to women and lower rungs of society, the absence of any kind of imposition of language as a medium of instruction from a central authority allowed basic education to be relatively widespread.

\section{Western Education and English as Language and Medium of Instruction in India}

\section{Missionaries: Duality of English and Vernacular Education}

The arrival of missionaries and the strengthening of the East India Company set the foundation for the demolition of the indigenous education system, and the consequent spread of English in education and public affairs. Through the establishment of schools, missionaries sought out to accomplish their project of proselytizing Indians, particularly the lower classes of Indian society, prior to 1813 . They expanded formal schools teaching western science, literature, and 
mathematics throughout British presidencies in the first half of the $19^{\text {th }}$ Century (Naik and Nurullah, 1974, pp. 38-57).

Instruction in vernacular languages, however, wasn't wiped away immediately, as the Danish missionaries i.e. the first missionaries to arrive in India, continued to conduct schools in Indian languages as the medium of instruction. These schools were established for European, AngloIndian, as well as converted-Indian children, and were also used as an instrument to teach English to facilitate better communication between the British and Indians. In fact, these missionaries were the first to introduce the printing of books and textbooks in Indian languages. The 'Serampore Trio' consisting of famous Danish missionaries- Dr. Carey, Ward and Marshman - facilitated the translation and printing of portions of the Bible, particularly the New Testament in over 31 Indian languages and dialects (Sherring, 1875).

Having initially begun the process of proselytization through the medium of Indian native languages with the support of the East India Company, rising tensions between the Company and missionaries around 1973 moved the dial towards proselytizing the Indian masses through the medium of English. Charles Grant (1792) was the first to propose this. He was of the opinion that European knowledge would throw light on and 'cure' the 'Hindoo darkness of ignorance and superstition', and this would best be done through the medium of English as opposed to Indian vernacular languages. He said:

superior, in point of ultimate advantage, does the employment of the English language appear; and upon this ground, we give a preference to that mode, proposing here, that the communication of our knowledge shall be made by the medium of our own language (Mahmood, 1895, pp. 11).

Thus, while Macaulay's Minute of 1835 is commonly thought to have been the first official attempt at the promotion of English as the medium of instruction, it was Charles Grant's proposal made over forty years before the Minute that started the debate.

\section{Colonial Debates on Medium of Instruction}

After the Charter Act of 1813, educating native Indians became one of the responsibilities of the East India Company. The charter resolution stated:

"A sum of not less than one lac of rupees in each year shall be set apart and applied to revival and improvement of literature and the encouragement of the learned natives of India and for the introduction and promotion of a knowledge of the science among the inhabitants of the British territories in India" (Sharp, 1919).

A controversy called the Anglo-Oriental Controversy arose in Bengal primarily regarding the objectives of education policy and the medium of instruction. The commencement of the Oriental language debate marked the beginning of what eventually culminated into three prominent language debates over the medium of instruction in education, which shadowed the sphere of language politics in India. 


\section{Orientalists}

Alongside the Missionary expansion of education in India, there was the rise of the Oriental school of education policy. Headed by the orientalist H.H. Wilson, this school of thought primarily advocated oriental learning of Sanskrit and Arabic studies, and the spread of western science and knowledge in these languages. Calcutta Madrassah and the Banaras Sanskrit College were the first to be set up as institutions to promote and ensure that the practices of previous Hindu and Muslim rulers were maintained (Naik \& Nurullah, 1974, pp. 36-38, 6790).

There were several who opposed the Orientalists' approach, both among the English officials and few influential Indians who had tasted the benefits of Western Education. The most notable was that of Raja Ram Mohan, who pushed for the inclusion of English as opposed to classical languages as a medium of instruction. Promoting the diffusion of European literature through English, he opposed the establishment of the Sanskrit College in Calcutta. In a letter to the Governor-General in December 1823, he opined:

"The Sangscrit system of education would be best calculated to keep this country in darkness, if such had been the policy of the British Legislature. But as the improvement of the native population is the object of the Government, it will consequently promote a more liberal and enlightened system of instruction, embracing mathematics, natural philosophy, chemistry and anatomy, with other useful science[s]" (as cited in Guha, 2010, pp.45).

Opposition to the inculcation of classical Indian languages from an Indian thinker was demonstrative of how several Indians themselves played a role in fueling the spread and demand for English. As a result of this, the General Committee of Public Instruction eventually made provisions for classes in English as well as Oriental languages.

\section{Anglicists}

Taking guidance from Charles Grant's initial proposal, Anglicists advocated for the use of English as the medium of instruction to convey Western literature and knowledge and promote the compulsory learning of Christianity.

The most prominent and influential votary of English education was Thomas Babington Macaulay. He was the President of the General Committee of Public Instruction in 1835 and a trusted aide of William Bentinck, the Governor-General of the EIC. In his Minute of 1835, he held the view that "promoting a knowledge of sciences could only be accomplished by the adoption of English as the medium of instruction". He disregarded classical languages like Sanskrit and Arabic as lacking literary merit and opined that the "appropriation of any of the funds which have hitherto been spent in encouraging the study of Arabic and Sanskrit would be downright spoliation". Rendering native languages to be meant for the purposes of poetry and imagination, he deemed English to be the language required when passing from "works of imagination to works in which facts are recorded and general principles investigated". Alluring to the supposed 'inherent' scientific nature of the English language, he deemed that "the 
dialects commonly spoken among the natives of...India contain neither literary nor scientific information", and therefore were "so poor and rude" that they were in need of enrichment (Sharp, 1919; Naik \& Nurullah, 1974, pp. 69-73).

The most significant impact of Macaulay's Minute was in the then Governor-General William Bentick's decision to pass the English Education Act of 1935, the objective of which was to promote the study of the sciences and European literature among Indian natives in the medium of English. Mandating that Indian natives indulge in the study of English literature, this Act invoked a complete shift in the nature of the Indian education system. However, the Act also faced opposition from Hindus and Muslims for the potential of anglicization because of the over-emphasis on Western ideals and language.

Macaulay's Minute also recommended that a separate class of Indians be equipped with the knowledge of English to serve as the middlemen between the rulers and ruled so as to facilitate better administration. What eventually resulted is exactly that: the creation of a 'Baburaj' i.e. a group of individuals well versed with the English language who could "understand [the British] and their concepts...[and] would freely give allegiance and loyalty to the British crown" (Ramanathan, 2005, pp. 32). The English babus thus came to constitute a group of local elites, who were meant to be the middlemen between the British and Indian natives, but gradually became the oppressors more than the interpreters, "proud of their status as brown sahibs, although never accepted as such by white sahibs" (Tully, 1997, pp. 159).

While several texts consider Macaulay's rhetoric to be pivotal to the spread of English in Indian education, it is important to understand that the superiority with which Indians perceived the English language already existed. Aware of the material prosperity that the knowledge of English brought, the Indian population longed to learn the language much before Macaulay's arrival to India. The more conservative officers of the Company, however, did not allow the widespread learning of English, which forced Indian natives to "quench their thirst [for English] in missionary schools" (Naik \& Nurullah, 1974, pp. 75). The arrival of Macaulay simply served as the stimulus for moving away from conservative policies and allowed for the introduction of new ideas.

\section{Anglo-Vernacular Controversy}

Both the Orientalist and Anglicist parties neglected the mother tongue as a medium of Instruction. However, a decade before Macaulay's Minute, there was conversation around the need to inculcate modern Indian languages in the Bombay Presidency, at least in secondary education, through good textbooks and well-trained teachers. This marked the beginning of the debate between imposing English versus Indian vernacular languages as the medium of instruction in education. 
The push for the study of Indian languages primarily came from Governor Mounstuart Elphinstone who pushed for the Bombay Native Education Society to take the lead in education policy. This Society was of the view that learning English was of secondary importance, as elicited in their 1825-26 report, which mentioned that the ideas of Western literature and science "will be most easily rendered comprehensible to them [Indian natives] by means of mother-tongue of each scholar" (as cited in Parulekar \& Bakshi, 1955, pp. 92). Thus unlike in the Bengal Presidency, there was a push not for classical but for mother tongue education.

\section{Push for the Vernaculars}

Within a few years after Bentinck's decision, the Government under Lord Auckland realized it was not possible to spread education among the masses through English languages. Much of Western education can be taught through vernacular Indian languages if good textbooks are prepared and teachers are trained. Because of this, the English Education Act had to be amended to allow for the proliferation of Indian vernacular languages and translation of English literature to Indian languages to make it more accessible to the Indian masses. Under Hendry Hardinge, in 1844, 101 vernacular schools were to be set up in Bengal (Ghosh, 2013). According to Suresh Chandra Ghosh (2013), “Bentick's decision opened the doors of Western literature and science to India, and ironically, it led to the promotion of vernacular languages and vernacular education."

Meanwhile, in Northwest Provinces, Lieutenant-Governor James Thomason proposed (184648) a scheme to set up a school in every considerable village, and a model school in every tehsil or revenue district with a Vernacular medium of Instruction. Lord Dalhousie endorsed the Thomason scheme of Vernacular education to be expanded to Bengal and Punjab. Dalhousie also recommended it to the Court of Directors to expand this as a national scheme of education. Many elements of the Thomason scheme made it to The Education Despatch of 1854 (Ghosh, 2013).

\section{English takes over in the Victorian Era (1854-1902)}

The Victorian Era was a period that saw the most rapid expansion of Westernization in education, as it was marked by the Charles Wood's Despatch of 1854, often referred to as the "Magna Carta of English Education in India" (Richey, 1922). This document was one of the first to lay emphasis on the expansion of mass education as a means to educating a larger proportion of the Indian population through the setting up of multiple primary, upper primary and secondary schools. While it recommended that vernacular languages be the medium of instruction in primary schools, it promoted the use of English at higher levels of education. It also laid emphasis on 'Westernization' and imparting western knowledge, ideals and cultural practices to the Indian natives (Richey, 1922). 
With the East India Company no longer being in power since 1858, the government of India fell directly under the Crown. Consequently, in stark contrast to the period before 1854 that was marked by war and a hostile attitude of Indians towards the British, the Victorian Era witnessed cordial and peaceful relations between the rulers and the ruled, and sentiments of suspicion towards the British were forgotten. This period of tranquility was instrumental in setting the foundation for the expansion of education (Naik \& Nurullah, 1974, pp. 148). As Indians became increasingly grateful for the British and were in admiration of their administration, there was naturally a more favourable attitude towards Western education, science and English literature. Missionary schools witnessed a drastic decline during this period as the Queen's Proclamation of 1858 demanded religious neutrality in education as a measure to assure the Indian population that there was no further threat of proselytization. Westernization of the character of Indian Education was brought to completion during the Victorian Era.

Lachman Khubchandani notes three patterns in the medium of instruction in the schools which emerged from the British rule in India (Khubchandani, 2008)

- Rural areas with primary education in vernacular languages

- A two-tier system with vernacular at primary level and English at higher stages in towns.

- The educated urban elites, English medium even at the primary stage

Although missionary schools had been instrumental in initiating the spread of the notion of the superiority of English as a medium of instruction in schools, it was during the exact period when missionary schools were no longer in the picture, that the most rapid expansion of English schools was seen through secondary education and universities. The gradual disappearance of indigenous schools over this period further added to the neglect of local languages in favour of English. Interestingly, most of the English medium high schools and universities were led by Indian managers, as the private Indian enterprise experienced rapid growth between 18541902. In 1881-82, about 55,000 primary schools were run by Indian managers, compared to 1,842 run by non-Indians, mostly by missionaries (See Table 4). By 1921-22, India had 1.66 lakh schools with 74 lakh students in schools and colleges of Western education. Unrecognized indigenous schools had reduced to 16,000 with just 4 lakh students studying in it (Nurullah and Naik, 1943, pp. 214). Only in higher education did the Missionaries have a lead. Owing to the greater opportunities that English education was thought to give its students, several of the provisions pertaining to the medium of instruction in vernacular languages in the Woods Despatch were not followed. 
Table 4: Educational Institutions run by Indian managers in 1881-82.

\begin{tabular}{|l|r|r|}
\hline $\begin{array}{l}\text { Educational Institutions in } \\
\mathbf{1 8 8 1 - 8 2}\end{array}$ & $\begin{array}{l}\text { Conducted by Indian } \\
\text { Managers }\end{array}$ & $\begin{array}{l}\text { Conducted by other than } \\
\text { Indian Managers }\end{array}$ \\
\hline Primary Schools & 54,662 & 1,842 \\
\hline Secondary Schools & 1,341 & 757 \\
\hline Arts Colleges & 5 & 18 \\
\hline $\begin{array}{l}\text { Professional Colleges and } \\
\text { Schools }\end{array}$ & 10 & 18 \\
\hline TOTAL & 56,018 & 2,635 \\
\hline
\end{tabular}

Source: Indian Education Commission Report 1882, reprinted in Naik \& Nurullah, 1974

At the secondary education level, the Education Despatch called for mother tongue instruction alongside education in English, however, in practice, education in the vernacular languages was completely neglected. It was observed that as of 1882, students were taught English even before they had a proper grasp of their own mother tongue. There were only four high schools teaching in the mother tongue as opposed to the 181 in English, fuelled by the excessive demand for education in English (Naik \& Nurullah, 1974, pp. 199). In many provinces (except in Bombay) even in early grades, English as a language was taught when the students were not properly grounded in his/her own mother tongue. Except in Punjab, the highest education that could be obtained through the mother-tongue was limited to the middle stage (Nurullah and Naik, 1943, pp. 298-300). Moreover, even the Indian Education Commission's attempt to remedy this situation did not seem to give too much importance to mother tongue education but favoured the continuation of English medium education instead.

The neglect of modern Indian languages at the secondary education level, therefore, led to a wider gap between Anglo and Vernacular languages and was also a significant factor for the continuation of English as a medium of instruction at both Junior College and university level. The missionaries, and then the British set the ball rolling for English education as language and medium of Instruction in India. It was the wholehearted adoption by Indians in the Victorian era, by setting up grant-in-aid schools and colleges that heralded massive anglicization of Indian education (Jolad, 2020 Aug 22).

\section{Printing in Indian Languages}

One important aspect of this era, however, was the introduction of new literature and the printing press in modern Indian languages. Educated Indians who had studied in English secondary education and universities, felt it was important to produce literature in modern Indian languages especially since they had been neglected over several years. These Indians took it upon themselves to translate much of the textbooks and newspapers from English to 
modern Indian languages, and consequently, much of the literature in modern Indian languages were fairly developed by 1902 .

\section{National Movement and Mother Tongue}

After the partition of Bengal in 1905, the swadeshi movement picked up the pace and trickled into the sphere of education. Lord Curzon's education policy also stirred up sentiments against the education system of the British and towards a more self-reliant system of education. Moreover, over 100 years of education by the British had barely resulted in an increase in the literacy rate. The movement for national education was thus at its peak from 1905-1921 and was primarily pioneered by Indians who had studied in the English education system and come to understand its defects. Before Gandhi, leaders like Gopal Krishna Gokhale, Bal Gangadhar Tilak, Lala Lajpat Rai and Annie Besant were the primary advocates of national education in India. The vision of the National Education included removal of the domination of English and usage of mother tongue/modern Indian languages as MOI (Naik \& Nurullah, 1974, pp. 300$302)$.

Lala Lajpat Rai spread the idea of national education primarily in Punjab. According to him, national education created by and for Indians was as important for the security of the nation as was the military. Education was to be the sole responsibility of the State without private intervention at the primary and higher education level (Lajpat Rai, 1920). Tilak's vision for national education was one that imparted knowledge with a balance of religious and industrial and political education (Mukhopadhyay, 2020). He also advocated that the study of foreign languages like English be reduced and replaced with the vernacular Indian languages. In his speech he mentioned:

But mere knowledge of the [English] language is no true education. Such a compulsion for the study of foreign languages does not exist anywhere except in India. We spend twenty or twenty-five years for the education which we can easily obtain in seven or eight years if we get it through the medium of our vernaculars. We cannot help learning English; but there is no reason why its study should be made compulsory. (Tilak \& Ghose, 1918).

Annie Besant advocated for developing a solid foundation through mother tongue instruction at the primary and secondary level of education, and English to be taught as a second language at the secondary level (Besant, 1932). According to her, students' knowledge of the mother tongue must be strong both from the "literary standpoint and from the point of view of the language as a medium of the expres-sion and communication of thought" (Besant, 1932, pp. 60). English should be taught through basic conversation from the age of eight and a more definitive study of the language must be during the last three years of secondary education. However, she never addressed the complexity that arose from the wide number of mother tongues within each state in India, in terms of choosing which language students would be educated in. Her plan to educate in the mother tongue of the district would become hard to implement owing to the immense linguistic diversity even within single districts. As a result, 
the question of the best way to practically implement a national education plan still remained unanswered.

In spite of the efforts of these visionaries, the national movement failed and came to an end by 1920 due to poor planning, lack of funds, and a stronger pull towards English education. National Education also degenerated as it was primarily used as means for national struggle, promoting ultra-narrow nationalism which asserted that India had nothing to learn from the West (Naik and Nurullah, 1974, pp. 203).

A reimagination of Indian education resurfaced much later through Gandhi's Wardha scheme in 1937 (Varkey and Hussain, 1940). This scheme emphasized manual and vocational education at the primary level in the mother tongue and advocated for Hindustani to be taught as the second language. In the case of pupils whose mother tongue is one that has no alphabet or literature, the language of the district was advised to take the place of the mother tongue in the scheme of education. Gandhi was strongly opposed to the learning of English in school as he wrote in Harijan in 1937:

English, having been made a Medium of Instruction in all branches of learning, has created a permanent bar between highly educated few, and the uneducated many. It has prevented knowledge from percolating to the masses. The excessive importance given to English has cast upon the educated class, a burden which has maimed them mentally for life and made them strangers in their own land (quoted in Varkey and Hussain, 1940, pp. 3)

Gandhi believed that if the component of learning English was eliminated, primary and secondary education could be combined to span over fewer years, and the students of this education would achieve higher levels of literacy compared to the matriculate of secondary education (Wardha Scheme- Basic Education). While this system of education was followed in certain provinces of India it fizzled out after World War II.

\section{In retrospect: the legacy of the past dominates the present}

In 2020, the National Education Policy stressed that attaining foundational literacy and numeracy for all children should become an urgent national mission. One of the reasons for the crisis of foundational learning is the disconnect between the language of the child at home and the language used in school for Instruction. Young children become literate in language and learn best through the language spoken at home. Although the importance of Instruction in the mother tongue/home language has been recognized in the constitution and iterated in the national policies post Independence, the medium of instruction in schools continues to be languages of political and economic clout like English, Hindi, and the dominant languages of the state. The perceived superiority of English and its utility for social and economic mobility has created a boom in budget private schools teaching in English. The root of dominant languages used in Indian schools as MOI can be traced back to the language politics from the 
colonial era. Thus there is a big disconnect between the science of language and learning among children and the practice followed language and medium of instruction in Indian schools.

In this article, we have traced the history and politics of language and medium of Instruction debate in Indian schools in the colonial era. We have first discussed the linguistic diversity of India, and the challenges it poses for mother tongue as MOI as the curriculum is centralized, teachers are not hired locally and books are in the dominant language of the state and the nation. The political hegemony of languages derives from the historic domination of classical languages in higher education in the pre-colonial era and its replacement by English in the colonial era. The language hierarchy so established resulted in the neglect of the vernacular languages in higher learning, and the near absence of dialects and tribal languages in schools.

In spite of the language hierarchy, indigenous schools in the 19th century were highly elastic and could provide elementary instruction in the language of the local region. The spread of formal school education and the centralized curriculum added rigidity to the schooling system. Thus a homogeneous schooling system was imposed on diverse socio-linguistic groups.

During the process of formalization of education in the colonial era, English emerged as a clear winner. Contrary to popular belief, the push for English as a language and medium of Instruction began much earlier than Thomas Macaulay, with the missionaries and their prominent advocate Charles Grant. The Anglo-Oriental and Anglo-Vernacular controversies played out in Bengal and Bombay presidencies before Macaulay. The anglicization of Indian Education blamed on a single man whose actual influence on Education Policy in colonial times did not last beyond a decade. The Education Despatch of 1854, Indian Education Commission Report 1882, or the Lord Curzon resolution on education 1904, show no endorsement of Macaulay's view on English medium at the primary level. English continued to dominate at the secondary schools and colleges, and in primary schools for the Urban elites. Widespread adoption of English in schools run by Indians in the Victorian Era spelt a death knell for indigenous schools, created aspiration for English education, and generated an attitudinal shift in India. English attained an aspirational status in the Victorian era, due to its employment potential with the British, window to the world, and as means for social and political reformation within the country.

Political awakening and National Movement in the late 18th and early 19th Century stirred a desire to create a self-reliant National Education System. The National Education envisioned by Tilak, Lala Lajpat Rai, Annie Besant had no place for domination for English and advocated the usage of mother tongue/modern Indian languages as MOI to be taught both for literary merit and as a medium of expres-sion. Later Mahatma Gandhi was even more critical of Western Education and accused English as MOI to be responsible for the class divide between educated few and the masses, and advocated Indian languages to be used at all levels of education.

Naik and Nurullah argue that at the end of the British era India had completely replicated Western Education from England, although the socio-economic background, the language and 
culture of both nations were very different (Nurullah \& Naik, 1974, pp. 406-411). They attribute the "disgracefully" low literacy, and education level of the mass at the time of Independence to the cheap imitation of all types of schemes and ideas that were evolved in England, imagining English to be the national language of India and advocating for its use as a medium of instruction at secondary and college level. 


\section{References}

Adam, W., \& Basu, A. (1941). Reports on the state of education in Bengal (1835 \& 1838).

[Calcutta]: University of Calcutta.

Agarwal, A., \& Jolad, S. (2020, July 12). The Pedagogical Problems of the Census. The India Forum. Retrieved from https://www.theindiaforum.in

Anand, S. (1999). Sanskrit, English and Dalits. Economic and Political Weekly, 34(30), 20532056. Retrieved May 19, 2020, from www.jstor.org/stable/4408224

Alam, M. (1998). The Pursuit of Persian: Language in Mughal Politics. Modern Asian Studies, 32(2), 317-349. Retrieved May 26, 2020, from www.jstor.org/stable/313001

Agnihotri, R. K. (2015). Constituent Assembly debates on language. Economic \& Political Weekly, 50(8), 47.

Arbuthnot, A. (1855). Selections from the Records of the Madras Government- II: Paper Relating to Public Instruction. Madras Presidency. Retrieved from http://14.139.60.153/handle/123456789/9113

Bajpai, R. (2008): "Minority Representation and theMaking of the Indian Constitution" in R Bhar-gava (ed.), Politics and Ethics of the Indian constitution (New Delhi: Oxford UniversityPress), pp 354-91.

Ball, J. (2010). Enhancing learning of children from diverse language backgrounds: Mother tongue-based bilingual or multilingual education in early childhood and early primary school years. Victoria, Canada: Early Childhood Development Intercultural Partnerships, University of Victoria.

Benedikter, T. (2013). Minority languages in India: An appraisal of the linguistic rights of minorities in India. Asien: Forschung und Wissenschaft/LIT Studies on Asia.

Besant, A. (1932). Principles of Education. Madras: Theosophical Publishing House.

Bühmann, D., \& Trudel, B. (2008). Mother tongue matters: local language as a key to effective learning (ED.2007/WS/56 REV.). UNESCO. Retrieved from https://unesdoc.unesco.org/ark:/48223/pf0000161121

Census India- C-16, 2011. (2018). ABSTRACT OF SPEAKERS' STRENGTH OF LANGUAGES AND MOTHER TONGUES - 2011. Registrar General of India.

https://censusindia.gov.in/2011Census/Language-2011/Statement-1.pdf

Constituent Assembly Debates [CAD], 1946-1950,the official report, Delhi University Library System, New Delhi; also at Indian National Archives, New Delhi; also see, http://parliamen-tofindia.nic.in/ls/debates/debates.htm 
Constitution of India. (2008), Retrieved from: https://www.india.gov.in/mygovernment/constitution-india/constitution-india-full-text

Calcutta : Office of the Superintendent of Government Printing, India, 11 v. in 20 : maps (part fold.) $; 36 \mathrm{~cm}$.

Daniyal, S. (2020, August 6). Why is India obsessed with English-medium education - when it goes against scientific consensus? Scroll Retrieved from https://scroll.in

Devy, G. N. (2014). Being in Bhasha: People's Linguistic Survey of India. General Introduction.

Dharampal. (1983). The Beautiful Tree: Indigenous Indian Education in the Eighteenth Century. New Delhi: Biblia Impex.

Eberhard, David M., Gary F. Simons, and Charles D. Fennig (eds.). 2021. Ethnologue: Languages of the World. Twenty-fourth edition. Dallas, Texas: SIL International. Online version: http://www.ethnologue.com.

Ethnologue. (2019, August 20). What countries have the most languages? Retrieved from https://www.ethnologue.com/guides/countries-most-languages

Ghosh, S. (2013). The History of Education in Modern India: 1757-2012 (4th ed.). Orient Black Swan.

Grant, C. (1792). Asiatic Subjects of Great Britain. In Parliamentary Papers (East India Company): Fourth Part Volume X. (1813). Great Britain: House of Commons.

Guha, R. (2010). Makers of Modern India. New Delhi: Penguin Group.

Grierson, G. A. (1903-1927). Linguistic survey of India (Vol. 1, Part 1: Introductory). Calcutta: Government of India.

Hasnain, S. I. (2012). Multilingualism, language policy and the constituent assembly debates. Language and Language Teaching, 1(2), 47-51.

Inspector General of Police- Madras. (1959). The History of the Madras Police: Centenary 1859-1959. Author. Retrieved from https://www.tamildigitallibrary.in

Jolad, S. (2020, August 22). On English-medium education, India is having the same debates it did 200 years ago. Retrieved from https://tinyurl.com/Jolad-Scroll-2020

Khaitan, S. (2020, August 12). Why Early Learning In Mother Tongue Is More Effective. India Spend. Retrieved from https://www.indiaspend.com

Khubchandani, L. (2008). Language Policy and Education in the Indian Subcontinent. In S. May \& N. Hornberger, Encyclopedia of Language and Education (2nd ed., pp. 369382). New York: Springer. 
Mahmood, S. (1895). A History Of English Education In India - Adopted under the British

Rule From Its beginning to the present period (1781 to 1893). Delhi, India: IDARAHI ADABIYAT-I DELL1.

Ministry of Human Resource Development. (2020, July). National Education Policy - 2020.

Retrieved from https://tinyurl.com/MHRD-NEP-2020

Mohanty, A. K. (2006). Multilingualism of the unequals and predicaments of education in India: Mother tongue or other tongue? In O. García, T. Skutnabb-Kangas, \& M. Torres-Guzmán (Eds.), Imagining multilingual schools: Languages in education and glocalization (pp. 262-283). Clevedon, Avon: Multilingual Matters.

Mohanty, A. K. (2008). Multilingual education in India. In J. Cummins \& N. H. Hornberger

(Eds.), Encyclopedia of language and education (Vol. 5, 2nd ed.). Bilingual education (pp. 165-174). New York: Springer.

Mohanty, A., Panda, M., Pal, R., Menken, K., \& Garcia, O. (2010). Language policy in education and classroom practices in India. Negotiating language policies in schools: Educators as policymakers, edited by Kate Menken, Ofelia García. (pp 211-231), Routledge.

Mukhopadhyay, R. (2020). Relevance Of Lokmanya Tilak’s Call For Education In Today's Times. International Journal Of Disaster Recovery And Business Continuity, 11(1), pp. 485-494.

Nurullah, S., \& Naik, J. P. (1943). History of education in India during the British period. Macmillan, Bombay.

Naik, J. P., \& Nurullah, S. (1974). A Students' History of Education in India (1800-1973)

(Sixth Revised Edition). Madras, India: Macmillan India Limited.

Parulekar, R. (1945). A Source Book of History of Education in the Bombay Province, Part I, Survey of Indigenous Education (1820-1830). Bombay.

Parulekar, R., \& Bakshi, C. (1955). Selections from Educational Records (Bombay) Part II (1815-1840). Bombay: Asia Publishing House.

Rai, L. (1920). The Problem of National Education in India. London: G. Allen \& Unwin. Ramanathan, V. (2005). The English-vernacular divide. Clevedon: Multilingual Matters. Richey, J. A. (1922). Selections From Educational Records Part II 1840-1859 (2).

Government of British India, Calcutta. Retrieved from http://14.139.60.153/handle/123456789/7198

Sharp, W. H. (1919). Selections from Educational Records- Part I: 1781-1839 (Vol. I). Calcutta, India: Bureau of Education, India. 
Sheth D.L. (2018) The Great Language Debate: Politics of Metropolitan Versus Vernacular India. In: deSouza P. (eds) At Home with Democracy. Palgrave Macmillan, Singapore. https://doi.org/10.1007/978-981-10-6412-8 10

Sherring, M. (1875). The History of Protestant Missions in India: From Their Commencement in 1706 to 1871. London: Trübner \& Co.

Tilak, B., \& Ghose, A. (1918). Bal Gangadhar Tilak: His Writings And Speeches. Madras: Ganesh \& Co.

Tully, M. (1997). English: an advantage to India?. ELTJournal, 51 (2), 157-164. doi: $10.1093 /$ elt $/ 51.2 .157$

UDISE- Ministry of Education, Government of India. (2017-2018). Universal District Information System of Education [Dataset]. Retrieved from https://udiseplus.gov.in/\#/Publication

UNESCO . (2009). UNESCO interactive atlas of the world's languages in danger. Retrieved October, 3, 2010. http://www.unesco.org/languages-atlas/index.php

UNESCO. (2016). If you don't understand, how can you learn? (ED/GEMR/MRT/2016/PP/24). Retrieved from https://unesdoc.unesco.org/ark:/48223/pf0000243713

Varkey, C. J., \& Hussain, Z. (1940). The Wardha scheme of education: An exposition and examination. Madras, India: Oxford University Press.

Ward, W., 1824, A View of the History, Literature, and Religion, of the Hindoos. Vol. I, p. 160. 